\title{
Contents Volume 5 (2009)
}

\section{Articles}

Beck Lassen, F., Regular, Dependable, Mechanical:

J.F. Struensee on the State of Denmark

Bond, N., Gemeinschaft und Gesellschaft: The Reception of a

Conceptual Dichotomy

Campos Pérez, L., Representing the Enemy: The Iconography of the "Other" in History Schoolbooks During the First Years of Franco's Regime

IhALAINEN, P., Introduction

Ihalainen, P., Towards an Immortal Political Body: The State

Machine in Eighteenth-Century English Political Discourse

Palonen, K., The Two Faces of Contingency: La Politique and

Le Politique in the Work of Pierre Rosanvallon

Pexonen, K., The European Idea of Ruling and Governing in the

Light of Conceptual History

Pertti Nokkala, E., The Machine of State in Germany - The

Case of Johann Heinrich Gottlob von Justi (1717-1771)

Pulkkinen, O., Political Bodies as Living Mechanisms in Scottish

Political Theory during the Late Eighteenth Century

Review Essays

Beck Lassen, F., Historisk tidskrift för Finland Vol. 92, nr. 1, 2007.

Theme issue on conceptual history entitled: Concept, Language and History

Marjanen, J., Slagmark. Tidsskrift for idéhistorie, 48 (forår 2007) ... 117

Ronnes, H., Erfgoed: de geschiedenis van een begrip 